FACULDADE DE CIÊ NCIAS ECONÔ MICAS DA UFRGS

REESTRUTURAÇÁ O DA PRODUÇÁ O AGRICOLA NO RIO GRANDE DO SUL, DE 1970 A 1996 E UMA ESTIMAÇȦ O PARA 2012 TIAGO WICKSTROM ALVES

A CRIMINALIDADE NA RECIAO METROPOLTANA DE SALVADOR JOSÉ CARRERA FERNANDEZ, LUIZ FERNANDO LOBO

COMPEIITIVIDADE INTERNACIONAL EM SOFTWARE: UM ESTUDO SOBRE A EXPERIÊNCIA DE FLORIANÓ POLIS HOVÉDO NUNES LINS

MODELOS DE ORGANIZAÇẢ O E REPARTIÇẢ O DE RENDAS NA CADEIA PRODUTIVA DO GÁS NATURAL.

HELder QUEIROZ PINTO Jú NIOR, RODOLFO TORRES dOS SANTOS

REGIMES MONETÁ RIOS E DIVIDA PÚ BLICA: UMA ANÁ LISE DE MECANISMOS ALTERNATIVOS DE COORDENAÇÃO MACROECONÓ MICA

manoel Carlos de Castro Pires

ECONOMIA DOS RECURSOS NATURAIS E SEUS INDICADORES DE ESCASSEZ: UMA QUESTÃ O DE SUSTENTABILIDADE ANDREA SALES SOARES DE AZEVEDO MELO

O ECOPROTECIONISMO AGRICOLA NA UNIĀ O EUROPEIA E SEUS POSSIVEIS IMPACTOS SOBRE A ECONOMIA BRASILEIRA Rodrigo daniel Feix, Clá udio R. Fóffano Vasconcelos

PADRÓ ES DE DESENVOLVIMENTO, FUNÇ Ó ES ESTATAIS E ENDIVIDAMENTO NO CAPITALISMO CONTEMPORÁNEO paulo Balanco, Eduardo Costa Pinto

A INTERNACIONALIZAÇÃO DO VAREJO A PARTIR DOS CASOS WAL-MART E CARREFOUR

Armando joảo dalla Costa

UMA ANÁ LISE ECONOMÉTRICA DO FUTEBOL BRASILEIRO ARI Francisco de Araujo JR, Clá udio D. SHIKIDA, LEONARDO M. MONASTERIO

O BRASIL E A ECONOMIA INTERNACIONAL: RECUPERAÇÃ O E DEFESA DA AUTONOMIA NACIONAL

RESENHA DE ALEXANDRE CÉ SAR CUNHA LEITE

REGIMES MONETÁ RIOS: TEORIA E A EXPERIÊNCIA DO REAL ResenHa de Fernando Ferrari Filho

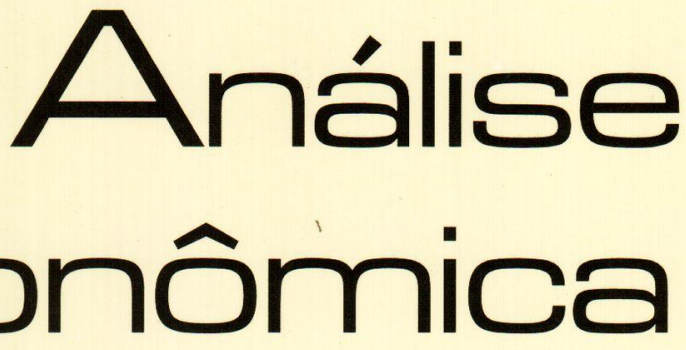


Universidade Federai. do Rio Grande do Sul Reitor: Prof José Carlos Ferraz Hemnemann

Facul dade de Cuéncias Economicas

Diretor: Prof. Gentil Corazza

Ceniro de Estudos f Prequisas Economicas

Diretor: Prof. Lovois de Andrade Miguel

Depariamenio de Crências Economicas

Chefe: Prof Ricardo Dathein

Departamento de Cîncias Coniábeis f A tuaria Chefe: Prof. Ceno Odilo Kops

Curso de Pós-Graduaçó em Economia

Coordenador: Prof. Fernando Ferrari Filho

Curso de Pos-Grainaça em Desenvolvimento RuRAI

Coordenador: Prof. Paulo Dabdab Waquil

Conseluo Eni tokial: André Moreira Cunha (UFRGS) Carlos G. A. Mielitz Netto (UFRGS), Carlos Henrique Hom (UFRGS). Eduardo A. Maldonado Filho (UFRGS). Eleutério F S. Prado (USP), Eugênio Lagemann (UFRGS), Fernando Cardim de Carvalho (UFRJ). Femando Ferrari Filho (UFRGS), Fernando de Holanda Barbosa (FGV/RJ), Flávio Augusto Ziegelmann (UFRGS), Flávio Vasconcellos Comin (UFRGS), Gentil Corazza (UFRGS), Giácomo Balbinot to Neto (UFRGS), Gustavo Franco (PUC/RJ) Hélio Henkin (UFRGS), Jan A. Kregel (UNCTAD), João Rogério Sanson (UFSC), Joaquim Pinto de Andrade (UnB), Júlio César Oliveira (UFRGS), Luiz Estrella Faria (UFRGS), Luiz Paulo Ferreira Nogueról (UFRGS), Marcelo S Portugal (UFRGS), Maria Alice Lahorgue (UFRGS), Octávio Augusto Camargo Conceicão (UFRGS), Paul Davidson (University of Tennessee), Paulo D. Waquil (UFRGS), Pedro C. D. Fonseca (UFRGS), Philip Arestis (University of Cambridge), Ricardo Dathein (UFRGS) Ronald Otto Hillbrecht (UFRGS), Sabino da Silva Porto Jr (UFRGS), Sérgio M. M. Monteiro (UFRGS), Stefano Florissi (UFRGS) e Werner Baer (University of IIIinois at Urbana - Champaign)

Comissão Emroniai: Eduardo Augusto Maldonado Filho, Fernando Ferrari Filho, Hélio Henkin. Marcelo Savino Portugal, Paulo Dabdab Waquil e Sérgio Marley Modesto Monteiro.

EnIrok: Sérgio Marley Modesto Monteiro

Ediror Adjun ro: Hélio Henkin

Secretário: Emerson Douglas Neves

REVISÃo DE IEX ros: Vanete Ricacheski

Emioração: Núcleo de Editoração e Criação da

Gráfica da UFRGS - Janaína Horn e Junia Saedt

Fundador: Prof Antonio Carlos Santos Rosa
Os materiais publicados na revista Análise Econômica são da exclusiva responsabilidade dos autores. É permitida a reprodução total ou parcial dos trabalhos, desde que seja citada a fonte. Aceita-se permuta com revistas congêneres. Aceitam-se, também, livros para divulgacão, elaboraça de resenhas e recensões Toda correspondência: material para publicação (vide normas na terceira capa), assinaturas e permutas devem ser dirigidos ao seguinte destinatário:

Prof. Sérgio Marley Modesto Monteiro Revista Andilse Económica - Av. João Pessoa, 52 CEP 90040-000 PORTO ALEGRE - RS, BRASIL Telefones: (051) $33163513 / 33164164$

Fax: (051) 33163990 - E-mail: rae@vortex ufrgs.br

A Revista Análise Econômica agradece a colaboração dos pareceristas do número 43, abaixo relacionados:

Adalmir Antonio Marquetti

André Moreira Cunha

Carlos José Caetano Bacha

Carlos Mielitz. Netto

Clailton Ataídes de Freitas

Claudio Roberto Fóffano Vasconcelos

Eduardo Ernesto Filippi

Eduardo Pontual Ribeiro

Eleuterio Fernando da Silva Prado

Fernando J Cardim de Carvalho

Fernando Augusto Mansor de Mattos

Fernando Ferrari Filho

Flávio Tosi Feijó

Flavio Vilela Vieira

Francisco Paulo Cipolla

Gentil Corazza

Gíacomo Balbinotto Neto

Helio Henkin

Jefferson Andronio Ramundo Staduto

João de Deus Sicsú Siqueira

José Carrera Fernandes

Leonardo Monteiro Monasterio

Luís Fernando de Paula

Luis Roberto Nascimento

Manoel Carlos de Castro Pires

Octavio Augusto Camargo Conceição

Patrízia Raggi Abdallah

Robson Antonio Grassi

Ronald Otto Hilbrech

Tiago Wickstrom Alves

Tito Belchior Silva Moreira

Análise Econônica

Ano 23, n ${ }^{\circ} 44$, setembro, 2005 - Porto Alegre

Faculdade de Ciências Economicas, UFRGS, 2000

Periodicidade semestral, março e setembro

1. Teoria Econômica - Desenvolvimento Regional -

Economia Agrícola - Pesquisa Teórica e Aplicada -

Periódicos. I.. Brasil

Faculdade de Ciências Econômicas,

Universidade Federal do Rio Grande do SuI

CDD 330.05

CDU $33(81)(05)$ 


\section{A internacionalização do varejo a partir dos casos Wal-Mart e Carrefour}

Armando João Dalla Costa

Resumo: Pelos dados da Wal-Mart, a Companhia tinha, no início de 2004, 1.478 lojas de descontos, 1.471 supercenters, 538 Sam's Clubs e 64 mercados de vizinhança nos EUA. Em outros nove paises operava 982 lojas de descontos, 257 supercenters, 80 Sam's Clubs e 36 mercados de vizinhança, totalizando 4.906 lojas. No mesmo ano, teve um faturamento bruto de US $\$ 256$ bilhões, um lucro líquido de US $\$ 6,6$ bilhões e contava com cerca de 1,6 milhão de empregados. $O$ Carrefour ocupa o segundo lugar entre as maiores empresas varejistas, vindo após a Wal-Mart, sendo o sexto maior empregador do mundo, com 419.000 funcionários, 42.687 no Brasil. Detinha, na França, 214 hipermercados, 1.003 supermercados, 459 maxidescontos, 1.520 mercadinhos e 159 Cash 8 Carry. Estava presente em cerca de 30 países, com aproximadamente nove mil lojas. Com este texto pretende-se entender as reestruturações empresariais implementadas na história dos dois grupos, assim como seu processo de internacionalização e a presença de ambas no mercado brasileiro.

Palavras-chave: Wal-Mart, Carrefour, Varejo, Mercado Internacional, Empresas.

Abstract: The Wal-Mart data shows that the company had, in the beginning of 2004, 1,478 discount stores, 1,471 supercenters, 538 Sam's Clubs and 64 neighborhood markets in the U.S.A. In other nine countries they operated 982 discount stores, 257 supercenters, 80 Sam's Clubs and 36 neighborhood markets totalizing 4,906 stores. In the past year, they made US $\$ 256$ billions, had a net profit of USS 6.6 billions, and employed about 1.6 millions of people. The Carrefour occupies the second place among the biggest retail companies, after the WalMart, being the sixth bigger employer in the world, with 419,000 employers, 42,687 only in Brazil. The Carrefour withheld, in France, 214 hypermarkets, 1,003 supermatkets, 459 maxi-discounts, 1,520 small markets and 159 Cash $\&$ Carry. In the last year they were present in about 30 countries, with approximately nine thousand stores. With this text it is intended to understand the enterprises changes implemented in the history of the two groups, as well as its process of internationalization and their presence in the Brazilian market.

Keywords: Wal-Mart, Carrefour, Retail International markets, Firms.

Jel Classification: L1 1, L22, LA4.

\footnotetext{
- Doutor pela Université de la Sorbonne Nouvelle Paris III. Professor Adjunto no Programa de Pós-Graduação em Desenvolvimento Econômico da UFPR e coordenador do Núcleo de Pesquisa em Economia Empresarial. E-mail: ajdcosta@ufpr.br. O autor agradece as importantes contribuições, críticas e sugestōes de parecerista da revista.
} 


\section{Introdução}

"As multinacionais já superam em poder econômico a maioria dos países do globo" (LAHÓZ e BLECHER, 2004, p. 108). Em 2004, o faturamento bruto da Wal-Mart foi de US $\$ 256$ bilhões, enquanto o PIB brasileiro em 2003 foi de US $\$ 497$ bilhōes, ou seja, uma única empresa tem um faturamento que supera a metade da produção de riquezas de nosso país.

O texto tem como objetivo entender a história da Wal-Mart e do Carrefour, as duas maiores empresas internacionais do varejo, assim como a estratégia empregada na ocupação dos mercados fora de seus países de origem. Estudará como ambas originaram-se nos negócios varejistas, sempre foram inovadoras em formatos de lojas e no uso intensivo de tecnologia, além de se apresentarem como intensivas em capital humano, destacando-se como a primeira e a quarta maiores empregadoras mundiais de mão-de-obra. Além disso, o texto visa acompanhar sua evolução nos quesitos que indicam o crescimento no aumento de lojas, número de funcionários e faturamento bruto.

Segundo Lahóz e Blecher (2004), não é de hoje que as multinacionais fazem parte da cena econômica mundial. Ainda no século XIX, empresas inglesas exploravam ferrovias em territórios inóspitos das Américas e da África. O objetivo aqui é entender a internacionalização das empresas de auto-serviço, que cresceram significativamente na segunda metade do século XX e sua internacionalização, que ocorreu a partir das últimas décadas do mesmo século. Neste contexto serão analisadas as estratégias de internacionalização da Wal-Mart e Carrefour, buscando entender como estabeleceram as disputas pelos mercados europeu, americano e asiático.

Para melhor compreender o fenômeno do investimento e da expansão no estrangeiro, recorreu-se à literatura que o analisa numa perspectiva voltada para um mundo globalizado. Ao se referir ao investimento direto estrangeiro, mencionam-se todas as formas de investimento em filiais através da construção de 'novas facilidades' ou de fusões e aquisições. A forma "tradicional" de investimento envolve o estabelecimento de plantas produtivas em mercados estrangeiros e expressa a aceleração da internacionalização produtiva (no nosso caso de estudo, comercial), assentada na crescente mobilidade do capital, da tecnologia e do conhecimento.

$\mathrm{O}$ investimento direto é realizado por empresas multinacionais que, em uma das primeiras definições, foram apresentadas como 
grandes companhias, com filiais em pelo menos seis países (VERNON, 1966) e que, a partir de discussões posteriores, esse limite foi reduzido a um país, além daquele de origem da firma.

As abordagens mais recentes procuram ressaltar o enfoque global da moderna corporação, definida como empresa de grande porte que, a partir da base estabelecida nacionalmente, estendeu sua atuação para o exterior através da implantação de filiais, seguindo uma estratégia e uma organização concebidas em escala mundial.

Saracini (2004, citando Chesnais 1996), destaca as características da empresa internacionalizada na seguinte ordem: a) a companhia transnacional é produto do processo de concentração e centralização do capital que a tornou "grande" no plano nacional; b) em geral, a empresa transnacional passou por um processo de diversificação produtiva antes de iniciar sua internacionalização; c) essa empresa tem uma origem nacional, de modo que suas estratégias e sua competitividade envolvem os pontos fortes de sua base nacional e o auxílio advindo do Estado; d) a companhia transnacional, em geral, é parte de um grupo contemporaneamente estabelecido como uma holding internacional; e) a atuação dessas companhias ou grupos se dá em escala mundial, através da definição de estratégias e da constituição de uma determinada organização para isso.

A adoção de uma conduta global implica a possibilidade de a firma adquirir participações acionárias em outros países. A definição adotada pelo FMI, a partir da primeira edição do Comparativo de Definições para o Investimento Direto no Estrangeiro (OCDE, 1983, in Toonoka, 1998), expressa as formas de poder que o investimento direto envolve, ressaltando também seu caráter estratégico. Assim, o IDE "designa um investimento que visa adquirir um interesse duradouro em uma empresa cuja exploração se dá em outro país que não o do investidor, sendo o objetivo deste último influir efetivamente na gestão da empresa em questão" (CHESNAIS, 1996, p. 55).

Para Saracini (2004, p. 13), um dos enfoques procurando explicar a lógica da realização da produção internacional tem como fundamento a existência de atributos únicos, específicos à firma (tecnologia, know-how, capacidade administrativa, sistemas de distribuição, controle das fontes de suprimentos), que conferem vantagens à firma e que constituem a motivação central para o investimento em mercados externos.

A expansão no mercado interno e externo - por meio do estabelecimento de filiais e subsidiárias, aquisições e/ou fusões - propicia o uso mais racional de fatores produtivos subutilizados. A exis- 
tência de serviços produtivos ociosos - tecnológicos, de escala, produtivos - é uma característica da firma capitalista. Dada essa condição, há uma propensão ao crescimento das firmas, porque a expansão propicia a redução dessa ociosidade e agrega ganhos de eficiência às firmas. A internacionalização das operaçōes apresenta-se como alternativa para tais ganhos.

Para autores como Penrose (1959), esse processo gera "economias" de crescimento identificadas como: a) ganhos derivados das plantas já existentes, provenientes de economias de escala, técnica e administrativa; b) ganhos derivados da expansão, como vantagens de custo em criação de demanda, política de marketing, entre outros.

Uma das dificuldades enfrentadas pelas firmas estrangeiras advém do conhecimento privilegiado das firmas nacionais em relação ao ambiente em que operam, lembra Saracini (2004). Considerando que ainda assim ocorre investimento direto, a suposição é de que existem contrapartidas que viabilizam as inversões no exterior. Isto significa dizer que a companhia estrangeira só consegue entrar no mercado externo e realizar investimentos porque possui algum tipo de atributo que compensa a maior exposição aos riscos e incertezas do ambiente (HYMER, 1960). A internacionalização das empresas acontece em função de um conjunto de ativos específicos que ela possui e que são únicos, definindo vantagens associadas às economias de escala, conhecimento, à existência de sistemas de distribuição, à diversificação dos produtos.

As multinacionais, ao decidirem expandir suas operações no exterior, observam uma série de elementos antes de escolher os países, tais como o estágio de desenvolvimento, o grau de industrialização, o tamanho do seu mercado interno, a logística de transporte e as condições políticas. As decisões também são afetadas pela prática de políticas protecionistas, custos de transporte, preços dos insumos, políticas e incentivos ao investimento direto estrangeiro.

De acordo com a análise de Dunning (1988), existem três condições necessárias e suficientes para a internacionalização das empresas: a) as firmas possuem atributos únicos que conferem vantagens monopolísticas em relação às firmas de outros países; b) além de dispor dessas vantagens, é mais proveitoso usá-las (internalizar suas atividades) em vez de vendê-las ou licenciá-las (externalizar suas atividades), pois essas vantagens seriam captadas por firmas de outros países; c) há vantagens em produzir externamente em certos países, ou seja, as condições vigentes no "mercado-alvo" são favoráveis, constituindo vantagens específicas do país hóspede da multinacional. 
Por fim, lembrando Guimarães (1982, p. 82), "Pode-se sugerir que a indústria oligopolística se move na direção de mercados mais amplos: dos mercados regionais para o mercado nacional e deste para o mercado externo". Como será discutido na seqüência, sobretudo para o caso da Wal-Mart, houve um início modesto no interior dos EUA para, em seguida, dar o avanço em direção ao mercado nacional para depois estabelecer-se no cenário externo.

\section{Wal-Mart e as inovações no varejo norte-americano}

Antes de construir a Wal-Mart, Sam Walton promoveu uma verdadeira revolução no varejo e exerceu um longo aprendizado de comerciante. Sam nasceu em Kingfischer, Oklahoma, em 1918, filho de Thomas Gibson Walton, e descreve assim o pai em sua autobiografia: "um personagem que gostava de fazer trocas, de negociar com qualquer coisa: cavalos, mulas, gado, casas, fazendas, carros. Foi o melhor negociador que conheci. Exerceu todos os tipos de atividades: banqueiro, fazendeiro, avaliador de fazendas, corretor de seguros e de imóveis" (WALTON, 1993, p. 3).

Formou-se em Comércio, na Universidade de Missouri, em 1940 e, logo em seguida, aceitou emprego na J.C.Penney, cadeia de lojas de miudezas, em Iowa, onde começou sua carreira de comerciante, trabalhando durante 18 meses, até os EUA entrarem na Guerra. Ao ingressar para o exército Sam tinha certeza de duas coisas: sabia que se casaria com Helen ${ }^{1}$ e que trabalharia no varejo para ganhar a vida. Em 1945, após a Guerra, decidiu ter seu próprio negócio. Helen concordou, mas impôs duas condições. Uma era a de que ele não deveria ter sócios e a segunda, que iria acompanhá-lo em qualquer lugar, desde que a cidade não tivesse mais que dez mil habitantes.

Em $1^{\circ}$ de setembro de 1945, Sam inaugurou sua loja de franquia da cadeia Bem Franklin, especializada em miudezas, em Arkansas. Foi ali, conhecendo seus concorrentes e colocando em prática as compras diretas dos produtores e vendas por preços baixos que Sam exerceu seu aprendizado de comerciante. Após cinco anos, com o

\footnotetext{
1 O casal teve quatro filhos: Robson, nascido em 28 de outubro de 1944, John (1946), Jim (1948) e Alice (1949). Robson formou-se em Direito, tornou-se o primeiro advogado da WalMart e participou da alta administração da companhia a partir de 1978. John T. Walton é administrador de imóveis, dirige as Empresas Walton e, a partir da morte do pai, em 1992, faz parte do Conselho de Administração da Wal-Mart. Jim e Alice trabalharam algum tempo na Wal-Mart, mas acabaram abrindo negócios próprios. Jim projeta e faz barcos à vela e dirige uma grande companhia de pulverização de plantaçōes, propriedade das Empresas Walton. Sam morreu no dia 5 de abril de 1992 e Helen (nascida em 1919), junto com os filhos, detêm $38 \%$ das ações da Wal-Mart (WALTON, 1993 e SLATER, 2003).
} 
vencimento do aluguel, foi obrigado a vender o estabelecimento, mudando-se para Fayetteville, em 1952, onde comprou a Walton's Five e Dime. Em seguida, associando-se com o pai e o irmão Bud, seus dois cunhados (NICK e FRANK), abriu lojas em Little Rock, Springdale e Siloam Springs, no Arkansas, além de outras em Neodesha e Coffeyville. "Num prazo de 15 anos passamos a ser a maior empresa independente de lojas de miudezas nos Estados Unidos. Em 1960 estávamos fazendo US\$ 1,4 milhão em 15 lojas" (WALTON, 1993, p. 38).

O grupo crescia, mas o resultado líquido não era satisfatório. Por isso, Sam e seus executivos, buscando uma alternativa mais rentável e lucrativa, interessaram-se pelos supermercados. $\mathrm{Na}$ época, o auto-serviço expandia-se nos EUA, o que levou os novos empreendedores a experimentarem esta forma de varejo.

Em 2 de julho de 1962 inaugurou-se a primeira loja Wal-Mart, ${ }^{2}$ em Rogers. Passados dois anos, foram abertas outras duas, em Springdale e em Harrison. "Em princípios da década de 1960 tínhamos 18 lojas de miudezas, sob os nomes de Bem Franklin e Walton e um punhado de Wal-Marts. As lojas de miudezas, aos poucos, foram substituídas por Wal-Marts" (WALTON, 1993, p. 48).

Em 1970 a empresa tinha 78 sócios, um total de 32 lojas, cada uma representando uma combinação diferente de capital entre diversos investidores. A família Walton era a maior acionista, mas Sam e Helen estavam muito endividados e por isso decidiram transformar a Wal-Mart em sociedade anônima. O primeiro lote de 300.000 ações foi vendido em $1^{\circ}$ de outubro de 1970 , a US\$16,50 cada, para cerca de 800 acionistas, arrecadando US $\$ 4,95$ milhões. "A família Walton ficou com $61 \%$ da Wal-Mart, mas pudemos pagar a todos os banqueiros e, a partir de então, não tomamos um tostão emprestado, pessoalmente, para manter a empresa. A abertura do capital ${ }^{3}$ realmente liberou a empresa para crescer e tirou dos meus ombros um grande peso" (WALTON, 1993, p. 89).

A estratégia para o crescimento acelerado, adotada daquele momento em diante, continuou seguindo a prática anterior. $\mathrm{O}$ foco

2. O nome Wal-Mart surgiu numa conversa entre Sam Walton e Bob Bogle, primeiro gerente da Walton's Five e Dime, numa viagem de avião. Bob sugeriu Wal, de Walton e Mart, que significa lugar de fazer compras, em escocês (WALTON, 1993, p. 40).

3 Para que os investidores se dispusessem a deixar Wall Street e acompanhar as reuniões anuais de prestações de contas em Fayetteville, estas foram transformadas em grandes eventos, com a presença de astros do esporte e da mídia. No dia 4 de junho de 2004 aconteceu "a maior reunião do Conselho de Administração de uma empresa no mundo, quando 15 mil pessoas se reuniram no estádio Bud Walton Arena. A delegação brasileira contou com 160 empregados do Bompreço" (MATTOS, 2004, p. B12). 
de crescimento se manteve a partir das pequenas cidades. O centro administrativo ficava em Fayetteville, no Arkansas, de onde partiam para ocupar os espaços vizinhos. Cada loja devia ficar, no máximo, a um dia de um centro de distribuição. "Íamos o mais longe possivel de um armazém e abríamos uma loja. A partir daí enchíamos o mapa daquele território, estado a estado, condado a condado, até que tivéssemos saturado aquela área de mercado" (WALTON, 1993).

Esta estratégia serviu para expandir a empresa para outros estados, mantendo Fayetteville como sede, até que, logo após a morte do fundador, a Wal-Mart atingiu os 50 estados norte-americanos.

Tabela 1: Wal-Mart e a ocupação do território americano - 1962-1995

\begin{tabular}{l|c|l}
\hline Anos & $N^{\circ}$ de estados com lojas & Estados inaugurando lojas nos respectivos anos \\
\hline 1962 & 1 & Arkansas \\
1971 & 5 & Louisiana, Missouri, Oklahoma \\
1973 & 6 & Tennessee \\
1979 & 11 & Alabama \\
1982 & 15 & Flórida, Nebraska \\
1983 & 19 & Indiana, lowa, Novo México, Carolina do Norte \\
1984 & 20 & Virgínia \\
1985 & 22 & Wisconsin, Colorado \\
1986 & 23 & Minesota \\
1990 & 34 & Califórnia, Nevada, Dakota do Norte, Dakota do \\
1991 & 42 & Sul, Pensilvânia, Utah \\
1992 & 45 & Connecticut, Nova Hampshire, Nova Gersey, \\
1993 & 49 & Delaware, Maine, Mariland, Nova York \\
1995 & 50 & Idaho, Montana, Oregon - Porto Rico \\
\hline
\end{tabular}

Fonte: http://www.wal-mart.com.ar Acesso: 13 ago. 2004.

Estando o foco de atuação voltado para as pequenas cidades, buscavam adaptar o tamanho das lojas aos potenciais consumidores de cada local. Adotavam cinco tamanhos diferentes, variando entre 2.700 e $3.500 \mathrm{~m}^{2}$, e dificilmente deixavam de lado um mercado por ser pequeno demais.

Como acontece freqüentemente nas empresas familiares, de início Sam acompanhava pessoalmente todos os contratos para aquisição de terrenos e abertura de novas lojas, assim como as tarefas administrativas internas, desde a comercialização, passando pelas 
operações imobiliárias, estudo da concorrência, financiamentos, contabilidade.

Uma das atividades que dava prazer a Sam era visitar as lojas e conversar com clientes, funcionários e gerentes. Quando a empresa cresceu, manteve este hábito, comprando aviōes ${ }^{4}$ para facilitar seu deslocamento, mas introduziu a prática de reunir todos os gerentes de lojas e os gerentes regionais nas manhãs de sábado. "É nas reuniões das manhãs de sábado que discutimos grande parte de nossa filosofia e de nossa estratégia administrativa: é o ponto focal de todos os nossos esforços de comunicação" (WALTON, 1993, p. 148).

Pelo fato de a empresa atuar em pequenas cidades, longe dos grandes centros urbanos, e representar uma pequena cadeia de lojas, era ignorada pelos distribuidores e atacadistas. Para contornar este fato, a empresa organizou seu próprio sistema de distribuição. Além disso, precisava de produtos de grandes companhias, como a Procter $\mathcal{B}$ Gamble, sendo que estas podiam muito bem vender as próprias mercadorias sem contar com a Wal-Mart.

Buscando resolver seus problemas de fornecimento e a um custo cada vez mais baixo, a partir de 1987, começou uma mudança no relacionamento entre as empresas produtoras e os varejistas. A WalMart propôs uma reunião entre os dez principais dirigentes de sua empresa com os da Procter $\mathcal{E}$. Gamble em Bentonville para dois dias de reflexões. Em três meses tinham criado uma equipe PÉG-WalMart para estabelecer um novo relacionamento entre fabricante e varejista. Com a partilha de informaçōes, a PEGG podia monitorar os dados de vendas e estoques da Wal-Mart e usar essas informações para preparar seus planos de produção e embarque de maneira muito mais eficiente.

Se no início os fornecedores não tinham interesse em vender seus produtos à Wal-Mart, quando a empresa cresceu esta realidade inverteu-se. Ao se tornar a maior distribuidora dos EUA, passou a pressionar os fornecedores para diminuírem constantemente seus preços. Hoje diz-se que "nos EUA o poder de barganha da Wăl-Mart é temido por todos os fornecedores" (DINIZ, 2004, p. 51).

4 "Teria sido impossível fazer o que fizemos então, se eu não tivesse os meus aviōes" (WALTON, 1993, p. 99). Os primeiros e pequenos aviöes de Sam evoluíram para uma frota mais moderna, como descreve Slater (2003, p. 125): "Para os vice-presidentes regionais, a rotina é toda segunda-feira pegar um dos 20 aviōes da empresa para diferentes partes dos EUA, visitar as lojas e gerentes, e voltar para casa na quinta-feira para as reuniōes do fim de semana". 


\begin{tabular}{l|r|c|c|c}
\hline Ano & Lojas & Empregados (em mil) & Vendas (em US\$ milhöes) & Lucro (em US\$ milhões) \\
\hline 1962 & 1 & & 30 & \\
1970 & 45 & & 1,24 & 1,2 \\
1980 & 330 & 27 & 25,8 & 40 \\
1990 & 1.525 & 328 & 78,3 & $1.000,0$ \\
1995 & 2.784 & 675 & 156,2 & \\
2000 & 3.989 & 1.200 & 180,7 & $6.271,0$ \\
2001 & 4.189 & 1.303 & 204,0 & \\
2002 & 4.641 & & 229,6 & $6,671,0$ \\
2003 & 4.688 & & 256,3 & \\
2004 & 4.906 & 1.600 & & \\
\hline
\end{tabular}

Fonte: Elaboração do autor a partir do material da empresa.

Talvez a característica mais marcante em Sam Walton tenha sido sua curiosidade e capacidade de analisar e conhecer as melhores práticas dos concorrentes e adaptá-las para seu negócio. "A Kmart sempre me interessou, desde a primeira loja em 1962. Eu ia constantemente às suas lojas porque eram um laboratório e eles eram melhores do que nós. Passei grande parte do meu tempo andando pelas suas lojas, conversando com seu pessoal e tentando descobrir comó faziam as coisas" (WALTON, 1993, p. 172).

Esta atitude Sam manteve até o final da vida. No início da década de 1980, percorreu a Alemanha, França, Itália, África do Sul, Grã Bretanha, Austrália e América do Sul. Voltou impressionado "com as gigantescas lojas Carrefour no Brasil" (WALTON, 1993, p. 180). A partir desta observação, decidiu lançar nos EUA os Hypermart, grandes lojas com mercearia e mercadorias em geral sob o mesmo teto. Entretanto, nos EUA os Hypermarts não se mostraram lucrativos o suficiente para se manterem funcionando. A partir desta experiência, a Wal-Mart desenvolveu o conceito dos Supercenters, combinação de mercearia e comercialização em geral, com tamanhos menores que os Hypermart. Este novo modelo de loja foi a base da forte expansão da empresa a partir do início da década de 1990.

No seu processo de crescimento, a Wal-Mart sofria pressões para envolver-se em negócios que não tinham nada a ver com o comércio, como as atividades industriais e serviços financeiros. David Glass, um de seus principais dirigentes, afirma que Walton e sua equipe estabeleceram a estratégia de investir apenas no comércio. "Desde 
cedo assumimos o compromisso de que nunca entraríamos em qualquer área que não fosse a de nosso negócio específico. Sabíamos fazer o que estávamos fazendo e juramos que continuaríamos a fazer a mesma coisa. Tudo estaria bem enquanto a Wal-Mart se mantivesse focada em sua única capacidade essencial, lançando boas lojas uma após a outra" (SLATER, 2003, p. 70).

Sem abrir mão desta estratégia, a Wal-Mart manteve-se aberta às novidades e necessidades no comércio. Atualmente trabalha com diversos formatos de lojas, desde os Sam's Clubs, passando pelas lojas de desconto, supercenters e mercados de vizinhança (Tabela 5).

Se os Hypermarts foram abandonados, o mesmo não se pode dizer dos Sam's Clubs. Trata-se de um conceito de loja do tipo armazém, destinado a proprietários de pequenos negócios e outros clientes que compram mercadorias por atacado. A primeira foi inaugurada em 1983 e, nove anos depois, já havia 217, com um faturamento de 10 bilhões de dólares.

Apesar do grande território norte-americano e de disputar o maior mercado do mundo, a Wal-Mart, em tempos de globalização, pensou em ser muito mais que uma empresa local. Sua internacionalização se impôs na medida em que estava pronta para disputar o mercado mundial. Este foi o desafio que se apresentou na passagem da década de 1980 para a de 1990 . O próprio fundador iniciou este processo, apesar de ter centrado suas atenções no mercado americano. No final de sua vida, afirmou "não sei se a Wal-Mart pode manter realmente a nossa posição de liderança ficando apenas nos EUA. Acho que teremos de nos transformar numa companhia mais internacional num futuro não muito distante" (WALTON, 1993, p. 184).

Em abril de 1992, mês da morte de Sam Walton, a Wal-Mart contava com 371.000 empregados, operava 1.714 lojas e 208 Sam's Clubs, nos Estados Unidos, mas tinha apenas seis supercenters e suas unidades no exterior limitavam-se ao México.

\section{Carrefour, os hipermercados e o varejo francês/europeu}

A história do Carrefour está repleta de transformações e inovações, assim como de dificuldades e desafios frente aos concorrentes, tanto na França e Europa, como nos demais continentes. A empresa iniciou suas atividades em 1959, quando foi criada a Sociedade Carrefour. No ano seguinte, foi inaugurado o primeiro supermercado Carrefour Parmelan, na Haute Savoie.

Em 1961 foi instituído o Promodis, nome inicial que, em seguida, se tornou Promodès e hoje é a insígnia adotada para as lojas de supermercados de toda a rede. Esta criação teve origem na fusão de 
dois comerciantes e atacadistas normandos, Paul-Auguste Halley e Leonor Duval-Lemonnier. No ano seguinte foi inaugurado o primeiro supermercado Promodès em Mantes-la-Jolie (YVELINES).

Se os primeiros supermercados franceses basearam-se na experiência desenvolvida nos Estados Unidos a partir dos anos 1930, a contribuição desta rede européia deu-se no sentido de apresentar um novo formato, maior e contendo mais elementos, que se tornou conhecido como hipermercado. Este novo conceito foi colocado em prática pelo Carrefour, pela primeira vez, em 1963 e consistia em vender tudo o que o consumidor precisa, fazendo apenas uma compra e indo a um único local, onde encontraria outra novidade: estacionamento de automóveis.

Neste mesmo ano o Carrefour inaugurou sua primeira loja de hipermercado em Sainte-Geneviève-des-Bois, com $2.500 \mathrm{~m}^{2}$ de superfície. A novidade foi abrir 400 vagas para estacionamento, uma vez que, após a Segunda Guerra deu-se a popularização do uso de automóveis e instituiu-se a prática de comprar todas as mercadorias para o consumo familiar sob o mesmo teto.

Uma das características do grupo é a inovação constante, buscando adaptar-se ao comércio local, tanto em formatos como adotando novas insígnias. A primeira mudança neste sentido ocorreu em 1969, quando os supermercados Promodès mudaram de nome, passando a chamar-se Champion, designação mantida até o presente.

Um dos desafios para as empresas poderem crescer é o acesso ao financiamento. Muitas firmas de origem familiar deparam-se com este limite na medida em que os recursos para investimento são escassos. No caso do Carrefour, seguindo o exemplo de muitas outras, a estratégia adotada foi a abertura de capital e a venda de ações em bolsas de valores. A primeira venda de ações ocorreu em 1970, quando o Carrefour foi introduzido na Bolsa de Paris.

$\mathrm{Na}$ busca por conquistas de fatias de mercado, assim como de novos clientes, mesmo entre as camadas pobres, uma inovação de meados da década de 1970 foi o lançamento de produtos "marcas próprias". Os supermercados passaram a ofertar mercadorias concorrentes às marcas tradicionais, embaladas com o símbolo da empresa e preço cerca de $30 \%$ menor, qualidade semelhante aos originais (uma vez que a matéria prima empregada é entregue pelos mesmos fornecedores). O grupo lançou seus produtos "marca Carrefour" a partir de 1976 e, daí em diante, passaram a ocupar lugar de destaque. 
Outra maneira de atrair maior clientela é trabalhar com descontos, ${ }^{5}$ processo que se intensificou no final dos anos 1970. Para tanto, organizaram-se lojas alternativas, com menos luxo nas instalações, menor número de funcionários, produtos colocados nas prateleiras dentro das próprias caixas, consumidores retirando as mercadorias das embalagens, tudo para diminuir custos e repassar menores preços. Em 1979 o Carrefour lançou a insígnia ED e a rede Champion, a insígnia Dia, com esta finalidade.

Além de lojas específicas como as acima mencionadas, cada vez mais instituições financeiras estão se associando a cadeias de varejo para vender produtos às classes C e D. ${ }^{6}$ Em 2004, no Brasil foram anunciadas nove parcerias entre estas instituições e as maiores redes varejistas. Destaca-se a associação entre o Pão de Açúcar e o Itaú, o Sonae e o Unibanco, e as Casas Bahia, que passaram a abrigar quiosques do Banco Popular, pertencente ao Banco do Brasil. ${ }^{7}$ Antes desta prática, eram as redes varejistas que financiavam compras em suas lojas através de cartōes próprios. O Carrefour lançou seu cartão de pagamento, Pass, em 1981. No Brasil, através do Cartão Carrefour podem ser adquiridas mercadorias nas lojas, inclusive fazendo prestações de produtos não alimentares, mais caros, como se fosse um cartão de crédito.

Uma das maneiras de os grupos do varejo ocuparem espaço de forma mais rápida é através da aquisição de concorrentes. O Carrefour recorreu a esta tática diversas vezes, tanto na França como em outros países. Em 1988, por exemplo, o Promodès comprou os 128 supermercados do Grupo Primistères e, em 1991 o Carrefour adquiriu o Euromarché e o Montlaur.

Além da aquisição, as empresas podem associar-se entre si, aumentando o capital e a capacidade de penetração em determinados mercados e/ou regiões. Exemplo desta forma de crescimento é o grupo Promodès, constituído em 1961, que se desenvolveu criando

5 A disputa por preços mais baixos é constante no marketing das empresas do setor. O Carrefour registrou em cartório, em 1980, o compromisso público de ofertar o menor preço ou pagar a diferença ao cliente (publicidade veiculada em rádio. Curitiba, 28 de outubro de 2004).

6 Existem diferentes formas de analisar as classes no sistema capitalista de produção, no entanto, o objetivo aqui não sendo este, utilizou-se classificação comumente empregada por empresas de marketing que distinguem as pessoas pela sua capacidade de consumo, a partir da renda auferida. Neste caso, pertencem à classe $\mathrm{A}$ os que ganham acima de 25 salários mínimos por mês ( $R \$ 6.500,00$, considerando-se salário de $R \$ 260,00$ ). Classe $B$, com ganhos entre 10 e 25 salários $(R \$ 2.600,00$ a $6.500,00)$; classe $C$, com ganhos entre 4 e 10 salários $(R \$ 1,040,00$ a 2.600,00); classe $\mathrm{D}$, com ganhos entre 2 e 4 salários (R $\$ 520,00$ a $1.040,00$ ); classe $\mathrm{E}$, com ganhos até 2 salários (até $\mathrm{R} \$ 520,00$ ).

7 SALOMÃO, Alexa. "A loja virou Banco. Porque cada vez mais cadeias de varejo estão se associando a instituiçōes financeiras para vender produtos bancários às classe $\mathrm{C} e \mathrm{D}$ ”. Revista Exame. Ano 38, edição 827, no 19, 29 de setembro de 2004, p. 50-54. 
diversos formatos de lojas e insígnias. Constituiu os hipermercados Continent, os supermercados Champion, os mercados de vizinhança 8 à Huit e Shopi, as lojas cash and carry Promocash, ofereceu serviços aos profissionais da alimentação fora de casa através do Prodirest e criou um site para vendas via internet, chamado Ooshop. Em 1999 fundiu-se com o grupo Carrefour, formando a segunda maior empresa mundial de distribuição. Na França, todos os hipermercados passaram a utilizar a insígnia Carrefour, e os supermercados passaram a se chamar Champion.

Outra forma de enfrentar a concorrência e continuar ocupando espaço no mercado é a constante adaptação das empresas às necessidades e exigências dos consumidores. Um dos desafios, neste sentido, é o atendimento a consumidores urbanos e sedentários que buscam produtos cada vez mais sadios e livres de agrotóxicos. Para atendê-los a empresa lançou a marca Carrefour Bio, em 1997, correspondente a uma linha de produtos biológicos.

Assim como nos demais setores da economia, a internet, uma vez difundida, exerce influência também no varejo. Para facilitar as compras e adaptar-se às novidades da geração do computador e internet, a empresa investiu, a partir de 2000 , nestas vendas, através do Ooshop.

Em 2004, o "Carrefour atua em 30 países, com mais de nove mil lojas, distribuídas nas Américas, Ásia e Europa". ${ }^{8}$

\section{Wal-Mart e sua expansão além fronteiras}

O sentimento predominante entre os dirigentes da Wal-Mart é o de que sua expansão internacional se dará em cerca de 20 países, sendo que a empresa já atua em cerca de dez. A estratégia de longo prazo para seu programa internacional é tornar a companhia realmente global. "Isso significa localizar parceiros globais para liderar as diferentes operações internacionais. Significa construir sistemas de distribuição e transporte globais. Significa desenvolver vínculos estreitos entre o lado americano e o lado internacional da empresa" (SLATER, 2003, p. 163).

Com este objetivo estratégico definido, a nova equipe dirigente ${ }^{9}$ lançou-se na internacionalização. Uma primeira decisão dizia

8 Dados disponiveis em http://www.carrefour.com.br/supermercado/carrefour/presenca.asp Acesso: 28 out. 2004.

9 Após a morte de Sam Walton, a direção executiva da empresa passou para a mão de profissionais contratados de fora da família, enquanto Robert Walton, seu filho mais velho permanece na presidência do Conselho Administrativo, caracterizando a administração como um misto de gerencia familiar e profissional. 
respeito aos países onde a empresa iria atuar. Após estudos internos e consulta a especialistas, chegaram à conclusão que "os critérios de escolha dos países deveriam ser a grande base demográfica e uma classe média forte e crescente".

$\mathrm{Na}$ estratégia de expansão além fronteiras, a empresa decidiu ocupar os mercados das Américas, da Ásia e da Europa. Durante a década de 1990, o programa internacional da Wal-Mart ostentou crescimento importante, desempenhando papel significativo no quadro financeiro. Em poucos anos, a Wal-Mart tornou-se o maior varejista do México e do Canadá e o terceiro maior do Reino Unido. Na América do Sul e na Europa, aparece apenas como coadjuvante. "Na Europa, enfrentando custos de mão-de-obra mais altos, sindicatos mais duros e um ambiente regulamentário mais paternalista que nos EUA, a Wal-Mart limitou sua atuação à Inglaterra e Alemanha" (SLATER, 2003, p. 149).

Como foi visto acima, mesmo antes da morte do fundador, a empresa atuava no México. Entretanto, a decisão estratégica de tornar a internacionalização um de seus pilares foi tomada pela equipe dirigente pós-Walton. Uma das primeiras medidas era a escolha de um dirigente que respondesse pela área, fizesse um planejamento e o executasse. $O$ executivo escolhido foi Bob Martin, que entrou na Wal-Mart em 1984 ocupando os cargos de vice-presidente executivo e vice-presidente sênior. Em 1993 David Glass e Rob Walton pediram-lhe para assumir como presidente e CEO da nova divisão internacional.

A tarefa de Bob Martin era transformar essa divisão num dos principais motores de crescimento da empresa. A expectativa era de que metade do crescimento da Wal-Mart derivasse de gêneros alimentícios, um terço das operações internacionais e, o resto, das lojas Wal-Mart nos EUA. Martin decidiu iniciar as operações internacionais pelas Américas do Norte e do Sul. Também tinha intenção de entrar na Ásia, tendo a China e Indonésia como pontos de partida e, por fim, entrar na Europa.

O início efetivo da internacionalização foi a aquisição das 122 lojas de descontos da canadense Woolco, em 1994. No entanto, entrar num novo mercado não significa imediatamente tornar-se lucrativo. Tanto é que, nos primeiros três anos, 1995-1997, a Wal-Mart do Canadá sofreu prejuízos de tal magnitude que Rob Walton um dia perguntou: "Será que alguém me lembraria por que entramos nesse negócio?" (SLATER, 2003, p. 152).

O México não apresentou as mesmas dificuldades, pela maneira como a empresa entrou, exercendo um aprendizado gradativo. A 
primeira loja foi inaugurada ainda quando Sam Walton vivia, ou seja, em 1991. Em meados da década, as expectativas naquele país eram favoráveis.

Procedimento semelhante foi adotado para a América do Sul, quando em 1995 a Wal-Mart instalou-se nas duas maiores economias da região: Brasil e Argentina. Nestes países iniciaram-se as operações com poucas lojas próprias, para experimentar e conhecer a cultura local e a forma de melhor atender seus clientes.

Como o mercado asiático tem características próprias e é muito diferente do ocidental, a maneira de ocupá-lo foi via associação com empresas locais. Em 1996, a Wal-Mart constituiu uma joint venture com a intenção de entrar na China e na Indonésia. Em 1999 adquiriu quatro lojas, entrando assim, na Coréia do Sul.

Com lojas próprias ou em parcerias nas Américas e na Ásia, faltava ocupar o mercado europeu. Para tanto, em 30 de dezembro de 1997 a Wal-Mart concluiu a aquisição de 21 hipermercados na Alemanha.

Uma vez conhecidos os mercados locais, a estratégia de expansão passou a depender das oportunidades que se apresentassem. Várias vezes a empresa, além do crescimento via construção de novas lojas, utilizou as aquisições para um crescimento mais rápido. Foi o caso do México, onde em 1998 adquiriu o controle do maior varejista, a Cifra, com lojas em todo o país, abrangendo desde a maior cadeia de restaurantes até uma loja de departamento de vestuário, tecidos e utensílios para o lar.

Em julho de 2004 a Wal-Mart operava 649 unidades comerciais em 64 cidades do México, incluindo auto-serviço, lojas de tecidos e restaurantes, empregando 105.365 pessoas. Suas ações são vendidas na Bolsa Mexicana de Valores desde 1977.

Tabela 3: Wal-Mart México: Bandeiras, número de lojas e percentual de vendas2004

\begin{tabular}{lccc}
\hline Bandeiras & Número de lojas & \% do total de lojas mexicanas & \% do total de vendas \\
\hline Sam's Clubs & 55 & 8,47 & 29 \\
Bodega & 144 & 22,18 & 29 \\
Wal-Mart & 83 & 12,78 & 27 \\
Superama & 46 & 7,08 & 6 \\
Suburbia & 50 & 7,70 & 5 \\
Vips & 271 & 41,71 & 4 \\
Total de lojas & 649 & 100 & 100 \\
\hline
\end{tabular}

Fonte: http://www.waltmartmexico.com.mx/acerca.html. Acesso: 12 ago. 2004. 
Estabelecer e/ou comprar filiais em outros países exige também um tempo de aprendizado e aculturação. A Wal-Mart passou por um duro aprendizado até conhecer o hábito de consumo e a melhor maneira de conquistar os consumidores locais. "Em 1995, quando chegou ao Brasil, vendia equipamentos para esquiar e tacos de beisebol. No Natal do ano seguinte, na tentativa de atrair consumidores, a empresa norte-americana teve de espalhar tendas pelos estacionamentos, pois a quantidade de itens que queria vender não cabia nas lojas" (MATTOS, 2004, p. B12). ${ }^{10}$

Em junho de 1999, Bob Martin deixou o cargo de chefe da divisão internacional, depois de construir um negócio de US\$17 bilhōes. Seu substituto foi John Menzer que entrou na Wal-Mart quatro anos antes como novo Diretor Financeiro. Ao assumir o cargo e após algumas pesquisas, descobriu uma regra prática para a entrada em novos mercados no exterior: demorava-se três anos para gerar lucro e cinco para atingir as metas de retorno.

A Wal-Mart, continuando a estratégia de expansão adotada por seu antecessor, uma de suas primeiras metas foi entrar no Reino Unido. Para isto, pagou US $\$ 10,8$ bilhões pela aquisição da ASDA, uma rede de 232 supermercados. A compra da ASDA, em junho de 2000, foi a maior da Wal-Mart até aquela data.

Essa cifra, no entanto, foi superada com a decisão de incluir o Japão entre os países de atuação da Wal-Mart. Após quatro anos de estudo do mercado japonês e de chegar à conclusão que seria melhor encontrar um sócio local, em 2002, a Wal-Mart pagou US $\$ 46,5$ bilhões por uma participação de 6,1\% na Seiy Ltda., quarta maior rede de supermercados do Japão e garantiu a opção de comprar outros dois terços até 2007.

Na sua internacionalização, a Wal-Mart construiu lojas próprias, associou-se a companhias locais e comprou concorrentes. As aquisições se repetiram na Alemanha, Inglaterra, México, Japão... No Brasil, a empresa crescia devagar, construindo lojas próprias, até chegar às 25, no início de 2004. Em março daquele ano, ao pagar US\$ 300 milhões ao grupo holandês Royal Ahold ${ }^{11}$ pelo Bompreço,

10 Se isto ocorreu no Brasil, nāo foi diferente nos demais países. Aliás, na Alemanha as dificuldades e o prejuízo foram bem maiores (SLATER, 2003, p. 155-157). A Ásia apresentou o maior desafio, uma vez que a cultura e as tradições são muito diferentes que as americanas. Naquela regiāo a Wal-Mart precisou ser reinventada. Sob o título "cobras vivas e corridas de tartarugas: Wal-Mart na China, Slater (2003, p. 161-179) descreve a atuação e os desafios da empresa no mercado chinês."

"O grupo Ahold chegou no Brasil em 1996, associando-se ao Bompreço, com base em Pernambuco. No ano seguinte comprou a rede baiana Supermar. Em 2001 adquiriu a sergipana G. Barbosa e em 2002 comprou nove das 16 lojas da maranhense Lusitana. A expansão levou o Ahold a deter cerca de $70 \%$ do mercado nordestino e atingir vendas de 4, 1 bilhões de reais em 2002, empregando 23.510 pessoas (MANO, 2003, p. 65). 
mudou de estratégia e passou a disputar o mercado nacional com seus principais concorrentes.

A aquisição alterou as posições entre as maiores empresas do setor, possibilitando uma economia de escala, com a qual "a gigante deve aumentar a tensão, já grande, entre indústria e varejo. Nos EUA o forte poder de barganha da Wal-Mart é temido por todos os fornecedores. Pela internet, a rede consegue comprar o que quiser pelo menor preço do mundo" (DINIZ, 2004, p. 51).

O Bompreço, almejado pelo Carrefour e Pão de Açúcar, além da Wal-Mart, fez com que aumentasse a disputa por redes regionais. A Wal-Mart, com esta aquisição, passou a ser a terceira maior do país, como pode-se observar pela tabela abaixo.

Tabela 4: Wal-Mart antes e depois da compra do Bompreço - 2004

\begin{tabular}{cccc}
\hline Situação & Faturamento (em R\$ bilhões) & Posição no Ranking - Brasil & Número de Lojas \\
\hline Antes & 1,7 & $6^{\circ}$ & 25 \\
Depois & 5,0 & $3^{\circ}$ & 143 \\
\hline
\end{tabular}

Fonte: Wal-Mart/Roland Berger. Citado por Diniz, 2004, p. 49.

Uma vez estabelecida nesses países, a Wal-Mart precisava compreender com rapidez as preferências dos clientes locais, como abastecer as lojas com eficácia e como lidar com os fornecedores. As novas lojas nos países estrangeiros precisavam inovar para serem competitivas, descobrindo, muitas vezes, maneiras novas e mais práticas de funcionamento que, na seqüencia, foram levadas para os próprios Estados Unidos.

$\mathrm{Na}$ arrumação das prateleiras foi utilizado o método brasileiro de reabastecimento, pelo qual os empregados repõem os estoques por trás de paredes internas, sem atrapalhar a movimentação dos clientes.

As lojas norte-americanas aproveitaram a experiência canadense na venda de sapatos, na forma de apresentá-los nas caixas e exibilos por estilo, ao invés de por tamanho. Para a exibição de vinhos seguiu-se prática oriunda do México, com nova forma de mostruário. Também no layout de gêneros alimentícios a inovação é mexicana. Na venda de roupas, trata-se de uma linha de roupas desenvolvidas no Reino Unido que também está sendo vendida nas lojas WalMart nos EUA e em outros lugares.

Em meados de 2004, a Wal-Mart estava presente em nove países fora dos EUA, totalizando 1.355 lojas (ainda não computadas as do Bompreço, adquiridas no Brasil no início do ano). Deve-se salientar 
que atua também no Japão, mas suas lojas não aparecem na conta gem, uma vez que a empresa ainda é sócia minoritária na Seiy Ltda.

Tabela 5: Wal Mart e a ocupação do mercado internacional-2004

\begin{tabular}{|c|c|c|c|c|c|c|}
\hline Pais & Ano da 1a loja & Lojas de Desconto & Supercenters & Sam's Clubs & Mercados de vizinhança & Total \\
\hline EUA & $1945 \cdot 1962$ & 1.478 & 1.471 & 538 & 64 & 3.551 \\
\hline México & 1991 & $487^{* *}$ & 83 & 53 & & 623 \\
\hline Porto Rico & 1991 & 9 & 3 & 9 & $32^{*}$ & 53 \\
\hline Canadà & 1994 & 231 & 4 & & & 235 \\
\hline Brasil & 1995 & & 13 & 10 & $2^{*}$ & 25 \\
\hline Argentina & 1995 & & 11 & & & 11 \\
\hline China & 1996 & & 28 & 4 & 2 & 34 \\
\hline Alemanha & 1997 & & 92 & & & 92 \\
\hline Coréia & 1999 & & 15 & & & 15 \\
\hline Reino Unido & 2000 & $255^{4+}$ & 12 & & & 267 \\
\hline Total Internac & & 982 & 257 & 80 & 36 & 1.355 \\
\hline Total Geral & & $\mathbf{3 . 4 6 0}$ & 1.728 & 618 & 100 & 4.906 \\
\hline
\end{tabular}

* Brasil inclui lojas Todo Dia.

** México inclui 140 Bodegas, 52 Suburbias, 44 Superamas, 251 Vips.

+ Porto Rico inclui 32 Amigos.

++ Reino Unido inclui 253 ASDA Stores e 2 George Stores.

Fonte: Dados disponiveis em http://www.walmart.com. Acesso: jul. 2004.

Pelas últimas declarações de seus dirigentes e pelos movimentos de ocupação do mercado internacional, percebe-se que as estratégias acima descritas estão sendo colocadas em prática. John Menzer, atual responsável pelos negócios internacionais, "diz que está de olho em todas as chances de novas compras no Brasil" 12 (MATTOS, 2004, p. B12). Afirma ainda que China, Índia, Rússia, México e Brasil são países vistos como oportunidades de expansão.

Apesar da crescente presença da Wal-Mart em dez países fora das fronteiras americanas, o desafio da internacionalização ainda não foi atingido. Estudos da McKinsey (DINIZ, 2004) mostram que, embora gigante, a Wal-Mart precisa crescer muito fora dos EUA, pois, entre as grandes empresas de varejo, ela é a menos internacionalizada. Apenas 13,3\% de suas receitas vêm de fora do seu país de origem, ante $31,1 \%$ no caso do Carrefour, uma das mais internacionalizadas.

2. Com vendas de 3,7 bilhōes de reais por ano e um total de 148 lojas, líder na Região Sul, o Sonae tornou-se uma das melhores opçōes de compra no setor. Assim como no caso do Bompreço, "o Wal-Mart é cotado como o mais provável comprador" (PADUAN, 2004, p. 60). Com o Sonae, o Wal-Mart estenderia sua atuação para o sul e se aproximaria do Carrefour em escala. O Carrefour, por sua vez, dono de $20 \%$ da empresa portuguesa Modelo Continente, controladora dos supermercados Sonae em todo mundo, poderia trocar essa participação pela operação brasileira. Expandir-se para o sul também faria sentido para o Pão de Açúcar, cujas lojas estão concentradas de Curitiba em direção ao sudeste. 


\section{Carrefour e sua precoce e eficiente internacionalização}

No atual mundo globalizado, não basta uma empresa ser competitiva e ocupar o mercado de seu país de origem. Para disputar as primeiras posições, faz-se necessário uma forte internacionalização. O Carrefour é um modelo de empresa que visa expandir seus negócios além das fronteiras francesas. Para tanto, adotou a estratégia de ocupar primeiramente os países europeus, seus vizinhos. Antes de comemorar seus primeiros 10 anos de história já estava presente na Bélgica e, alguns anos depois, chegou à Espanha, país que ocupa a segunda posição em importância após a França.

Na década de 1970, além da Espanha ocupou apenas outro país, o Brasil, onde chegou em 1975, estabelecendo-se com lojas próprias, a partir de São Paulo. Os anos 1980 representaram o avanço em direção a outros dois países como a Argentina, onde ocupa hoje a primeira posição, com 22 hipermercados situados na Grande Buenos Aires. Além disso, detém o controle da sociedade Supermercados Norte, líder da distribuição alimentar naquele país.

A expansão latino-americana continuou com a abertura da primeira loja no México, em 1994, que evoluiu até os 19 hipermercados atuais. Completou-se com a inauguração do primeiro hipermercado em Bogotá, na Colômbia, onde conta atualmente com cinco lojas.

O Carrefour começou a ocupar o mercado asiático a partir de 1989, ao ser inaugurado o primeiro hipermercado em Taiwan. Hoje o grupo administra 26 hipermercados, além de ter desenvolvido novos conceitos, como a Ótica Carrefour, a partir de 1998.

Em seguida foi a vez da Malásia receber a primeira das atuais seis lojas de hipermercados, em 1994. A China foi o país seguinte, com a primeira loja inaugurada em 1995. Atualmente, o Carrefour é o maior distribuidor estrangeiro implantado naquele país. Com 27 hipermercados o grupo está presente na maioria das grandes cidades chinesas: Pequim, Xangai, Shenzhen, Tianzin, Nanjin e Chongquin. Com a inauguração do primeiro hipermercado no Japão, em 2000, o Carrefour passou a ter lojas em sete países asiáticos.

A internacionalização é importante, mas a base de sustentação do grupo encontra-se em seu país de origem. Apesar de estar presente em outros sete países europeus, a França representa 59,3\% do faturamento europeu. A Espanha vem em segundo lugar, com 18,2\%, seguida da Itália e Bélgica que, juntas representam quase o rendimento espanhol, com $16,5 \%$. 
Tabela 6: Carrefour e a ocupação do mercado internacional - 1969-2004

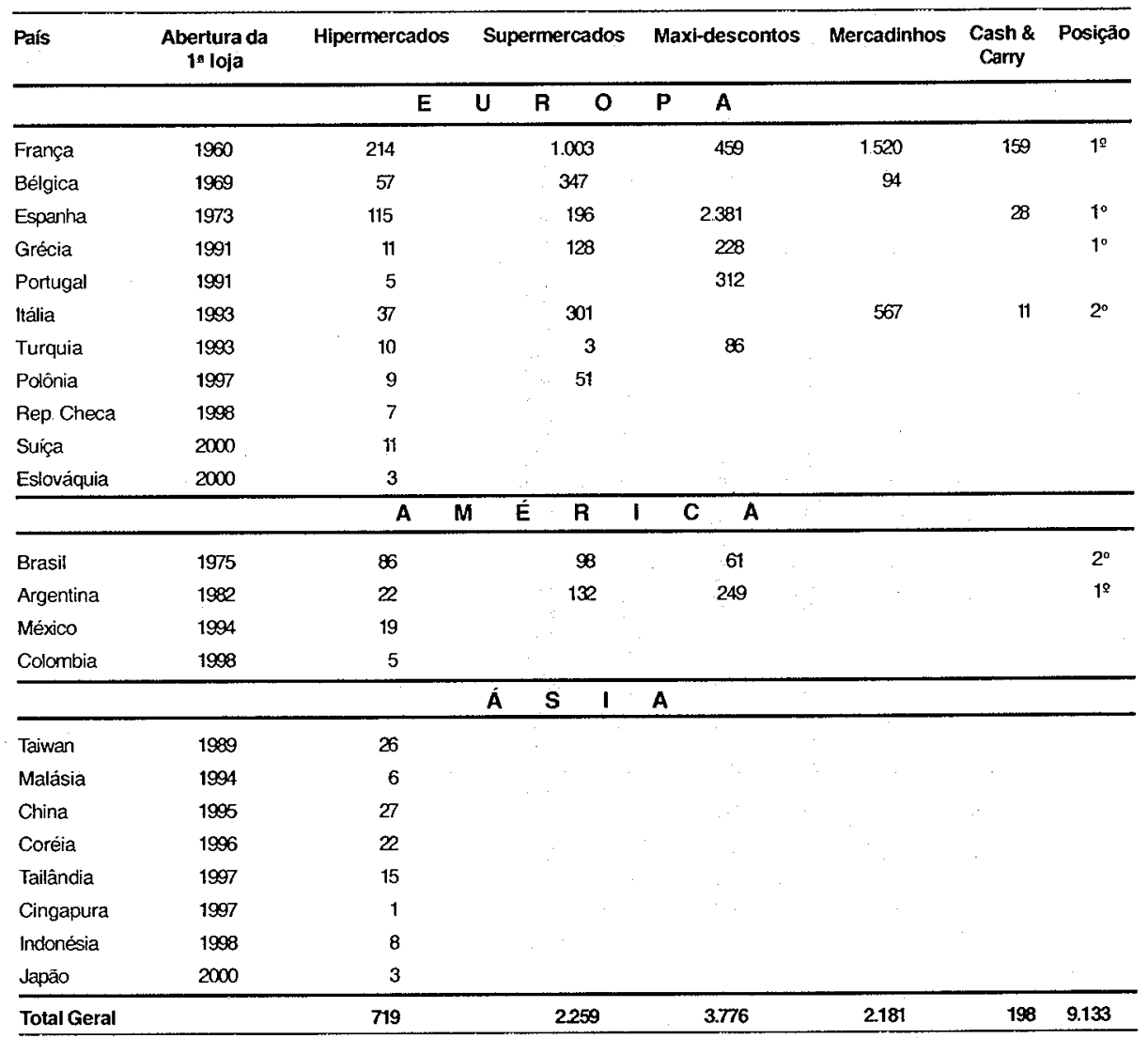

Fonte: O Carrefour no mundo (com dados relativos ao ano de 2001). Disponível em http://www.carrefour.com.br/carrefour/presenca.asp. Acesso: 12 Jun. 2004.

Tabela 7: Importância dos países europeus para o Carrefour - 2004

\begin{tabular}{|c|c|c|c|c|c|c|}
\hline Pais & $\begin{array}{l}\text { Faturamento } \\
\text { (milhoes Euros) }\end{array}$ & $\begin{array}{l}\text { Hipermerc. } \\
\text { Carrefour }\end{array}$ & $\begin{array}{l}\text { Supermerc } \\
\text { Champion }\end{array}$ & $\begin{array}{l}\text { Maxi-descont, } \\
\text { ED, Dia\% }\end{array}$ & $\begin{array}{l}\text { Mercados } \\
\text { vizinhança }\end{array}$ & $\begin{array}{c}\text { Cash \& } \\
\text { Carry }\end{array}$ \\
\hline França & 35.704 & 216 & 1.005 & 588 & 1.611 & 155 \\
\hline Espantha & 10.932 & 124 & 200 & 2566 & & 32 \\
\hline Itália & 5.733 & 40 & 379 & & & 13 \\
\hline Bélgia & 4.129 & 56 & 271 & & 156 & \\
\hline Grécia & 1.618 & 13 & 101 & 278 & 51 & \\
\hline Portugal & 979 & 7 & & 355 & & \\
\hline Polónia & 713 & 15 & 67 & & 13 & \\
\hline Rep. Tcheca & 376 & 13 & & & & \\
\hline
\end{tabular}

Fonte: http://www.carrefour.com/stages/fr/zone_eur.html. Acesso: 01 out. 2004. 
Observando a expansão das lojas no período escolhido, existem três aspectos que chamam a atenção. O primeiro é a direção para onde se encaminham as novas lojas. Das 34 inaugurações, 19 foram em países asiáticos e, dentre elas, nove na China, indicando que este país foi escolhido como prioritário nos investimentos de expansão. O ritmo de crescimento também chama atenção, pois trata-se de quase três inaugurações por mês.

$O$ segundo destaque se refere à relação entre o tamanho das lojas e os empregos criados. Na Colômbia, uma loja com $8.123 \mathrm{~m}^{2}$ gerou 748 vagas de trabalho, enquanto na Grécia, uma loja com $8.300 \mathrm{~m}^{2}$, um tamanho semelhante, gerou apenas 250 empregos. É de se supor que onde os salários são mais elevados (União Européia), os empregados são submetidos a uma carga de trabalho maior que onde os salários são mais baixos (América Latina) ou então, existe uma "mecanização" (labor/saving) maior do varejo nos países centrais que nos periféricos.

Uma terceira observação está na forma de utilização dos meios de transporte para dirigir-se aos supermercados. O convencional é reservar vagas para estacionamento de veículos. No entanto, no Japão e em Taiwan as lojas prevêem estacionamento para "duas rodas", ou seja, bicicletas e motos. Na China, aparece uma terceira modalidade, que é o "transporte a pé", indicando que o mercado localiza-se apenas 10 minutos a pé da residência. Novamente aparece o aprendizado internacional, de adaptação às condições de cada país e de cada local.

Corroborando a informação da Tabela 8 e analisando o faturamento do primeiro semestre de 2004, percebe-se claramente a opção pelo investimento no mercado asiático, que cresceu 13,7\% contra $1,9 \%$ da América Latina, como pode-se ver pela Tabela 9. No total do grupo, o faturamento aumentou em $4 \%$ e em todas as regióes de atuação, com exceção da França, onde a empresa passou por um processo de reestruturação administrativa e de composição das lojas.

Além dos aspectos acima mencionados, pode-se perceber o dinamismo da empresa no mercado internacional, analisando os principais movimentos de compras, associações e vendas de empresas, entrada e saída de atuação em diferentes países. Só em 2003 , o Carrefour comprou os hipermercados Hyparlo, na Itália e passou sua participação de $55 \%$ para $100 \%$ no Carrefour Colômbia. O Ed, insígnia francesa de maxidesconto do grupo, assinou protocolo de acordo com a sociedade de distribuição alemã EDEKA Sud Ouest, prevendo a aquisição de 44 lojas sob a insígnia Treff Marche, o que 
permite o início de atuação do Carrefour na Alemanha. Por outro lado, a empresa vendeu os sete hipermercados que tinha no Chile para o grupo DESS.

Tabela 8: Carrefour - Inaugurações de novas lojas entre maio de 2003 e agosto de 2004

\begin{tabular}{|c|c|c|c|c|c|c|}
\hline País & Data & $\mathrm{N}$ de lojas & $\begin{array}{c}\text { Área de } \\
\text { venda }\left(\mathrm{m}^{2}\right)\end{array}$ & Caixas & $\begin{array}{c}\text { Vagas de } \\
\text { estacionam. }\end{array}$ & $\begin{array}{c}\text { Empregos } \\
\text { criados }\end{array}$ \\
\hline China & 25.08 .04 & 51 & 8.510 & 51 & & \\
\hline México & 05.08 .04 & 29 & 7.500 & 40 & 599 & 366 \\
\hline Colômbia & 29.07 .04 & 13 & 6200 & 36 & 624 & 384 \\
\hline Grécia & 29.07 .04 & 15 & 8.300 & 38 & 1.100 & 250 \\
\hline China & 29.07 .04 & 50 & 9.300 & 53 & 300 & \\
\hline China & 29.06 .04 & 49 & 6.293 & 42 & 200 & \\
\hline Taiwan & 20.06 .04 & 33 & 8.000 & 19 & $\begin{array}{l}850 \text { carros } \\
5002 \text { rodas }\end{array}$ & \\
\hline China & 290404 & 1 sup. & 1.500 & & & \\
\hline China & 17.03 .04 & 44 & 11600 & & & \\
\hline Romênia & 15.02 .04 & 3 & 9000 & & & \\
\hline Colômbia & 220204 & 12 & 8.123 & 50 & & 748 \\
\hline China & 17.02 .04 & 42 & 6.500 & 49 & 120 & \\
\hline Jạpāo & 23.01 .04 & 8 & 11.000 & & $\begin{array}{l}1.483 \text { carros } \\
3292 \text { rodas }\end{array}$ & 500 \\
\hline Taiwan & 18.12 .03 & 31 & 8242 & 26 & $\begin{array}{l}500 \text { carros } \\
5602 \text { rodas }\end{array}$ & \\
\hline México & 12.12 .03 & 27 & 6.785 & 24 & & 350 \\
\hline Tailândia & 15.12 .03 & 19 & 11.000 & & & 500 \\
\hline México & 09.12 .03 & 26 & 5.500 & 18 & 1.500 & 323 \\
\hline Polônia & 06.12 .03 & $14 \in 15$ & & & & \\
\hline Chile & 25.11 .03 & 7 & 7.082 & 44 & 492 & 340 \\
\hline Turquia & 21.11 .03 & 5 superm. & 1200 & 10 & 78 & 62 \\
\hline Rep. Tcheca & 19.11 .03 & 9 & & 1200 & 420 & \\
\hline China & 28.10 .03 & 2 Dia\% & 350 & & 10 min à pé & \\
\hline Espanha & 28.10 .03 & 123 & 9.500 & 44 & 1.500 & 650 \\
\hline Colômbia & 23.1003 & 10 & 10.700 & $\mathscr{2}$ & 1.226 & 371 \\
\hline Chile & 22.1003 & 6 & 6.982 & 36 & 485 & 310 \\
\hline Espanha & 221003 & 122 & 7500 & 34 & & 250 \\
\hline Јара̃o & 15.10 .03 & 6 & 10000 & & 1.400 & \\
\hline Tailândia & 15.1003 & 18 & 7.600 & 31 & 830 & 500 \\
\hline Japão & 01.1003 & 5 & 9.000 & & 1.000 & \\
\hline Romênia & 24.09 .03 & 2 & 8.400 & 56 & 1.400 & \\
\hline China & 18.09 .03 & 41 & 9345 & 49 & 350 & \\
\hline México & 30.08 .03 & 24 & & & & 235 \\
\hline México & 22.08 .03 & 23 & & & 479 & 315 \\
\hline China & 05.08 .03 & 40 & 6.600 & 45 & & \\
\hline
\end{tabular}

Fonte: http://www.carrefour.com/francais/groupecarrefour Acesso: 2 set. 2004. 
Tabela 9: Desempenho do Carrefour no mundo - Primeiro Semestre de 2004

\begin{tabular}{lccc}
\hline Regiöes do mundo & $\begin{array}{c}\text { Faturamento bruto- } 1^{\circ} \text { semestre } \\
2004 \text { (em rnilhöes de Euros) }\end{array}$ & $\begin{array}{c}\text { Faturamento bruto- } 1^{\circ} \text { semestre } \\
\text { 2003 (em milhöes de Euros) }\end{array}$ & $\begin{array}{c}\text { Taxa de crescimento } \\
\text { (em \%) }\end{array}$ \\
\hline França & 17.068 & 17.173 & $-0,6$ \\
Europa (sema França) & 12.775 & 12.049 & 6,0 \\
América L.atina & 2241 & 2198 & 1,9 \\
Asia & 2465 & 2.168 & 13,7 \\
Grupo & 34.549 & 33.583 & 4,0 \\
\hline
\end{tabular}

Fonte:http://www.carrefour.com/francais/infosfinancieres/chiffreAffairesResultats2001.jsp. Acesso: 2 set. 2004.

\section{Conclusão}

As atuais redes de varejo no mercado internacional, baseadas no auto-serviço, são relativamente recentes uma vez que os supermercados surgiram na primeira metade do século passado. Tanto a Wal-Mart como o Carrefour iniciaram sua história na década de 1960 , como pequenas empresas familiares e se tornaram a primeira e segunda maiores empresas mundiais do setor em poucas décadas.

Apesar de estarem focadas no mercado internacional, sua presença no país de origem é determinante na sua pujança. A Wal-Mart, mesmo estando presente em nove países fora das EUA, é lá que concentra a maioria de suas lojas. De um total de 4.906, 3.551, ou seja $72,4 \%$ estão no mercado norte-americano. O Carrefour, se contar. mos apenas a Europa, onde atua em oito países, a França representa, com 3.555 lojas, 59,3\% do faturamento (35,7 bilhões de Euros).

As duas são inovadoras em conceitos de lojas e na busca de novos formatos no atendimento aos consumidores. A Wal-Mart criou os supercenters a partir da experiência dos hipermarts, adotados com base nos hipermercados. Desenvolveu o conceito dos Sam's Clubs, sempre na área do varejo, para atender lojistas e pequenos comerciantes.

O Carrefour criou os hipermercados como inovação maior e, na seqüência, trabalhou com os conceitos de supermercados de vizinhança, lojas de hard discount, mercados especializados para atender os profissionais do setor de alimentação, um setor voltado às refeições fora de casa, supermercados de vizinhança com horário especial, e vendas pela internet. Nesta gama de diferentes serviços prestados no varejo, conta atualmente com 17 formatos de lojas: Carrefour, Champion, Shopi, Dia, 8 à Huit, Proxi, Ed, Promocash, Prodirest, Marché Plus Proximité, Super GB, Di per di, GS, Punt/Cash, Docks e Ooshop. ${ }^{13}$

${ }_{13}$ Dados sobre as diferentes marcas e insignias do Carrefour, com o histórico de cada marca e sua situação internacional, disponiveis em http://www.carrefour.com/francais/notreoffre/ champion.htm. Acesso: 29 jun. 2004. 
Diferente de outros setores da economia em que o processo de oligopolização e monopólios iniciou-se na segunda metade do século XIX e/ou no início do século XX, o varejo destaca-se pela pulverização e pelo grande número de empresas. Até porque se trata de uma atividade específica, envolvendo diversos aspectos como cultura, atendimento ao cliente, relação fornecedor-produtor-logística, vizinhança, nichos específicos, entre outros, que as multinacionais e os grandes conglomerados não conseguem atender a contento.

No aspecto da internacionalização, ambas disputam os mesmos mercados europeu, americano e asiático. Por motivos compreensiveis, embora estejam presentes nestas mesmas regiões, a WalMart não atua na França, assim como o Carrefour não está presente nos EUA.

Na internacionalização, o Carrefour não só saiu na frente, como mantém uma larga vantagem. Lançando sua primeira loja na França em 1962, em 1969 estava presente na Bélgica e conta atualmente com $33,4 \%$ de sua receita do mercado internacional. A Wal-Mart tem espaço para crescer fora de suas fronteiras de origem, como no mercado interno. Ainda tem apenas $13,1 \%$ de sua receita proveniente do mercado internacional e só ocupa cerca de $9 \%$ do mercado interno, enquanto a maior empresa inglesa detém cerca de $30 \%$ do mercado doméstico.

Uma das características dos autores que estudam a internacionalização do capital, como Chesnais (1996), é de que estes investimentos se revestem de 'interesses duradouros'. Analisando-se os dois casos apresentados, percebe-se exatamente este fenômeno, uma vez que o Carrefour já se encontra no Brasil há 30 anos e não há nenhum indicativo que tenha intenção de abandonar este mercado.

Como pode-se observar, as multinacionais investem no estrangeiro baseadas em 'atributos específicos' (SARACINI, 2004), tais como tecnologia, know-how, capacidade administrativa, sistemas de distribuição, controle das fontes de suprimentos, que conferem vantagens às firmas. Neste caso, tanto Wal-Mart como Carrefour, desenvolveram um saber-fazer que lhes permite vantagens comparativas com as empresas locais dos diferentes países em que atuam.

Para Hymer (1960), as multinacionais observam, antes de escolherem os países, seu estágio de desenvolvimento, o grau de industrialização, o tamanho do mercado interno, a logística de transporte e as condições políticas. Nos casos de Wal-Mart e Carrefour, apesar de atuarem nos mercados americano, europeu e asiático, acontece exatamente isto, ou seja, implantam-se apenas onde há viabilidade 
para o lucro, não tendo, por exemplo, nenhum caso de implantação no continente africano.

Seguindo a análise de Guimarães (1982), as firmas começam pelo mercado regional, expandem para o nacional e depois ocupam o externo. No entanto, ter lojas em outros países não significa lucro imediato. É preciso levar em conta a cultura e os hábitos alimentares, assim como as maneiras próprias de gerenciar o varejo e de atender os clientes. Por isso, o lucro só chega após alguns anos de experiência. Outro fator a destacar é que, tanto no mercado interno como no exterior, as empresas cresceram construindo lojas próprias, fazendo joint-ventures, associando-se e comprando concorrentes.

Destaque-se a importância da internacionalização para a melhoria contínua no gerenciamento das lojas, na troca de experiências e no aproveitamento das boas idéias, que são disseminadas nas filiais dos demais continentes.

Apesar da internacionalização ainda não estar totalmente consolidada no ramo do varejo em auto-serviço, a experiência destas duas empresas aponta para uma forte disputa nos anos vindouros, pelas melhores fatias e os mais significativos países do mercado europeu, americano e asiático.

\section{Referências bibliográficas}

ABRAS - Associação Brasileira de Supermercados. Revista SuperHiper. São Paulo: Abras, ano 27, n. 309, maio de 2001. Vários números dos anos 1990 e 2000.

CAMARGO, Alessandro Mancio. "Novo conceito. Inaugurada no mês de julho, a nova granja Ideal Por anuncia parcerias com integrados e assina acordo de fornecimento para o Carrefour". Revista Suinocultura Industrial. São Paulo: Gessulli, edição 180, ano 26, n 6, p. 32, 2004 .

CHESNAIS, François. A mundialização do capital. São Paulo: Xamã, 1996.

DALLA COSTA, Armando João. "A importância da logística no varejo brasileiro: o caso do Pão de Açúcar". Cadernos da Escola de Negócios da Unibrasil. Curitiba: Unibrasil, n², Jan/Jun. p. 65-84, 2004.

DALLA COSTA, Armando João. "Wal-Mart e suas reestruturações empresariais para disputar o mercado mundial do varejo". IV Colóquio Latino-Americano de Economistas Políicos. São Paulo: FGV, 31 de outubro a 02 de novembro de 2004.

DALLA COSTA, Armando João. "O Carrefour e a disputa pelo varejo no mercado internacional”. II Seminário de Pesquisa ell Seminário de Iniciação Científica da Uniandrade. Curitiba: Uniandrade, 19 de novembro de 2004.

CARREFOUR Enseignes et Marques. Dados gerais da empresa, disponíveis em http:// www.carrefour.com/francais/notreoffre/champion.htm. Acesso: 29 Jun. 2004.

DINIZ, Daniela. "O bicho-papão acordou. Ao comprar o Bompreço a Wal-Mart dá sinais de que vai entrar para valer no jogo do varejo no Brasil". Revista Exame. São Paulo: Abril, ano 38, ed. 813, n 5, p. 48-50, 17 de março de 2004. 
DUNNING, John. The ecletic paradigm of international production: a restatement and some possible extensions. Journal of international Marketing Business Studies. London, v. 19, n. 1, p. 1-31, springs, 1988.

EXPORTAÇÕES chinesas para os EUA. 12\% do total vão para as prateleiras da rede WalMart. Revista Exame. São Paulo: Abril, ano 38, edição 827, n 19, p. 79, 29 de setembro de 2004.

GREENHOUSE, Steven. "Wal-Mart intriga intelectuais dos EUA. Sociólogos e historiadores fazem simpósio só para tentar entender o fenômeno da ultrapoderosa cadeia varejista". Jornal Folha de S.Paulo. Caderno Mundo, p. A28, 18 de abril de 2004.

GUIMARÃES, Eduardo A. Acumulação e crescimento da firma. Rio de Janeiro: Zahar, 1982.

HYMER, Stephen. The international operations of national firms: a study of direct foreign investment. Tese de Doutorado. Cambridge: Massachussets Institut of Technology, 1960.

http://www.abras.org.br Sítio da Associaçāo Paranaense de Supermercados. Várias consultas em 2004.

http://www.abrasnet.com.br Sítio da Associação Brasileira dos Supermercados, com dados do varejo nacional. Várias consultas em 2004.

http://www.asda.com Sítio da Wal-Mart na Inglaterra. Várias consultas em 2004.

http://www.carrefour.com.br Várias consultas em 2004.

http://www.carrefour.fr Várias consultas em 2004.

http://www.champion.fr Várias consultas em 2004.

http://www.dia.es Várias consultas em 2004.

http://www.ed-fr.com Várias consultas em 2004.

http://www.promocash.com Várias consultas em 2004.

http://www.shopi.com Várias consultas em 2004.

http://www.walmart.com Sítio com dados dos Estados Unidos e da empresa de modo geral. Várias consultas em 2004.

http://www.wal-mart.com.ar Várias consultas em 2004.

http://www.walmart.com.br Várias consultas em 2004.

http://www.walmartcanada.ca Várias consultas em 2004.

http://www.wal-martchina.com Várias consultas em 2004.

http://www.walmartgermany.de Várias consultas em 2004.

http://www.walmartkorea.com Várias consultas em 2004.

http://www.walmartmexico.com.mx Várias consultas em 2004.

http://www.walmartpr.com Sítio de Porto Rico. Várias consultas em 2004.

LAHÓZ, André e BLECHER, Nelson. "Dúvidas sobre o lugar dos grupos brasileiros no mundo". Revista Exame. São Paulo: Abril, ano 38, ed. 830, no 22, p. 108-114, 10 de novembro de 2004.

LUZ, Cátia. "Indústria do desconto. Empresas se adaptam à queda de renda dos brasileiros e lançam produtos cada vez mais simples e baratos", in: Revista Época. Rio de Janeiro: Ed. Globo, n³16, p. 46-48, 7 de junho de 2004.

MANO, Cristiane. "Quem vai se dar bem? Como a venda do Bompreço, do grupo holandês Royald Ahold, deverá desencadear um novo movimento de consolidação do setor de supermercados no Brasil", Revista Exame. São Paulo: Abril, ano 37, ed. 799, n 17, p. 64-67, 20 de agosto de 2003. 
MATTOS, Adriana. "Wal-Mart admite erros e faz planos no Brasil”. Rede americana diz que país está na lista de investimentos e que pretende manter preços até $7 \%$ inferiores aos da concorrência. Jornal Folha de S.Paulo. Caderno Dinheiro, p. B12, 6 de junho de 2004.

NAPOLITANO, Giuliana. "O Banco do Dr. Abilio. Pão de Açúcar segue tendência mundial e faz parceria com o Itaú para financiar clientes". Revista Exame. São Paulo: Abril, ano 38 , ed. 823, no 15, p. 94-95, 4 de agosto de 2004.

O Carrefour no mundo. Disponivel em http://www.carrefour.com.br/carrefour/ presenca.asp. Acesso: 12 Jun. 2004.

PADUAN, Roberta. "Três vezes em cinco anos. No ano passado o Brasil vendeu 340 milhões de dólares em frutas frescas no mercado externo, quase o triplo de 1998". Revista Exame. São Paulo: Abril, ano 38, edição 829, n 21, p. 62-64, 27 de outubro de 2004.

PENROSE, Edith. Foreign investment and growth of the firm. Oxford: Basil Blackwell, 1959 SALOMÃO, Alexa. "A loja virou Banco. Porque cada vez mais cadeias de varejo estão se associando a instituições financeiras para vender produtos bancários às classe C e D". Revista Exame. São Paulo: Abril, ano 38, edição 827, n 19, p. 50-54, 29 de setembro de 2004.

SARACINI, Terezinha. A expansāo das empresas transnacionais alimentares nos anos de 1990 e suas estratégias para o Brasil. Tese de Doutorado. Curitiba: UFPR, 2004.

SCOTT, Lee. "The everyday price cutter". The Economist. Vol. 372, n 8.392 (First published in Sepetember 1843), p. 62, September 11th 2004.

SLATER, Robert. Wal Mart. Como a nova geraçăo de líderes transformou o legado de Sam Walton na empresa \# I do mundo. Rio de Janeiro: Campus, 2003.

TEIXEIRA, Michelly. “O avanço das multis. O que muda no agronegócio quando gigantes multinacionais do setor compram marcas, companhias e terras no Brasil". Revista Exame. Edição Especial: O futuro do agronegócio. São Paulo: Abril, encarte da edição 825 , ano $38, n^{\circ} 17$, p. $44-46,1^{\circ}$ de setembro de 2004.

TOONOKA, Eduardo K. Investimento direto japonês na década de 80: uma análise dos seus determinantes no Brasil e no mundo. Tese de Doutorado. Faculdade de Economia, Administração e Contabilidade. São Paulo: USP, 1998.

VERNON, Raymond. International investment and international trade in the product cycle. The Quartely Journal of Economics. Cambridge: Harvard University, v. 80, n. 2, may 1966.

WAL-MART. Relatórios Anuais 1972-2004. Disponíveis em http:/www.walmart.com. Várias consultas em 2004.

WALTON, Sam; HUEY, John. Made in America. 4. ed. Rio de Janeiro: Campus, 1993. 